\title{
Psychiatric Morbidity among Patients Admitted with Dengue Fever
}

\section{Dang Humması İle Başvuran Hastalarda Psikiyatrik Morbidite}

\author{
Uvais NA $^{1}$, Shamsudeen Moideen ${ }^{2}$ \\ ${ }^{1}$ Iqraa International Hospital and Research Centre, Dept. of Psychiatry, Calicut. \\ ${ }^{2}$ Iqraa International Hospital and Research Centre, Dept. of Internal Medicine, Calicut, Kerala, India
}

\begin{abstract}
Objectives: To study the prevalence of psychiatric disorders or symptoms and psychotropic prescription patterns among patients who admitted with Dengue fever.

Materials and Methods: In this descriptive study, discharge summaries of all the patients admitted with Dengue fever in a medical unit of the hospital from June 2017 to October 2017, were reviewed and details of psychotropic prescriptions, psychiatric consultations and psychiatric diagnosis were collected. Results: About 14 patients (5.71\%) received psychotropic medication during admission. Only 4 patients received psychiatric consultation. Out of 14 patients, 9 patients were prescribed clonazepam, 3 patients were prescribed quetiapine. Rest of the patients received sertraline, and amitriptyline.

Conclusion: In view of the recent epidemics of Dengue in various Indian states and all over the world, it is important to evaluate the burden of the disease on mental functioning, as untreated psychiatric illness can lead to increased medical morbidity, higher healthcare costs, and can delay or prevent recovery from medical illness.

Key words: Psychotropics, Dengue fever, anxiety, depression
\end{abstract}

$\ddot{O} \mathbf{z}$

Amaç: Dang humması ile başvuran hastalardaki psikiyatrik bozuklukların veya semptomların ve psikotropik reçete sıklığının yaygınlığının araștırılması.

Materyal ve Metot: Bu tanımlayıcı çalışmada, Haziran 2017 - Ekim 2017 tarihleri arasında hastanenin tıbbi birimlerinde Dang humması ile başvuran tüm hastaların taburculuk özetleri gözden geçirildi ve psikotropik reçete, psikiyatrik konsültasyon ve psikiyatrik tanı detayları alındı.

Bulgular: Yaklaşık 14 hastaya (\% 5.71) başvuru sırasında psikotropik ilaçlar verilmişti. Sadece 4 hasta psikiyatrik konsültasyon almıștı. 14 hastanın g'unda klonazepam, 3'ünde ketiapin reçete edilmiști. Hastaların geri kalan kısmına sertralin ve amitriptilin verilmişti.

Sonuç: Çeşitli Hint ülkelerinde ve dünyada son zamanlardaki Dang humması salgınları nedeniyle, hastalığın zihinsel ișlevlere etkilerini değerlendirmek önemlidir, zira tedavi edilmeyen psikiyatrik hastalıklar tıbbi morbiditenin artmasına, sağlık masraflarının yükselmesine, iyileșme sürecinin gecikmesine veya ortadan kalkmasına sebep olabilir.

Anahtar kelimeler: Psikotropikler, dang humması, anksiyete, depresyon

\section{Correspondence / Yazıșma Adresi:}

Dr. N. A. Uvais

Iqraa International Hospital and Research Centre, Calicut, Kerala / India

e-mail: druvaisna@gmail.com

Date of submission: 29.12.2017

Date of admission: 19.03.2018

\section{Introduction}

Dengue infection is an important and most common mosquito-borne, acute febrile illness in the tropical world. In the last two decades Dengue fever has emerged as the most important arthropod-borne viral disease of humans and the frequency of Dengue fever epidemics has increased dramatically over a geographically expanding range. ${ }^{1}$ First outbreak of Dengue hemorrhagic fever, a severe form of the illness, was reported in Asia in the 1950's and thereafter it spread throughout South East Asia and became 
the leading cause of morbidity and mortality among the pediatric population in this region. $^{2}$ Due to the presence of overcrowding in cities with unsafe drinking water and inadequate sanitation, continued rural to urban migration, and low vaccination coverage, India is at a high risk for Dengue outbreaks and every year Dengue fever outbreaks occur in different parts of the country. ${ }^{3}$

Dengue fever is caused by four antigenically distinct single strand positive-polarity RNA viruses, belonging to the family Flaviviridae. ${ }^{4}$ Viral transmission in its simplest form involves the ingestion of viremic blood by mosquitoes and passage to a second susceptible human host. The classical Dengue fever is a biphasic illness beginning abruptly 3-8 days after the mosquito bite, characterized by fever, headache, malaise and generalized muscle, joint, or bone pain. Improvement after several days is followed by the reappearance of fever and development of a measles-like rash, generalized lymphadenopathy, and occasionally minor hemorrhagic manifestations. The disease resolves in the second week, but the patient may experience prolonged convalescence, with weakness and depression. ${ }^{4}$

In addition to the classical hematological manifestation, there are also other atypical psychological manifestations of Dengue. ${ }^{5}$ A Google and PubMed search revealed three cases of psychosis, five cases of mania, one case of catatonia and two cases of unspecified behavioral alterations, associated with Dengue infection. The fatal outcome is also mentioned in those Dengue cases with psychological manifestation. ${ }^{6}$ Despite the high prevalence of this illness, the exact incidence of neuropsychiatric manifestation of Dengue infection is not certain due to the lack of adequate studies. There is thus an urgent need to conduct such studies in order to assess the impact of Dengue on mental health.

\section{Materials and Methods}

To study the prevalence of psychiatric disorders or symptoms and psychotropic prescription patterns among patients admitted with Dengue fever, we conducted a study in a medical unit of a 250-bedded tertiary care hospital in Calicut, Kerala, India. It was a descriptive study. Discharge summaries of all the patients admitted with Dengue fever in a medical unit of the hospital from June 2017 to October 2017, were reviewed and details of psychotropic prescription, psychiatric consultation and psychiatric diagnosis were collected. The study was approved by the Ethical Review Board of the Hospital. Descriptive statistical analysis was done with the help of Statistical Package for Social Sciences (SPSS) version 17.

\section{Results}

Out of 245 admissions, 14 (5.71\%) patients received psychotropics. Out of 14 patients, 8 were males $(57.10 \%)$. The mean age of the patients were 47.14 years (SD: 16.60 ) with age range from 18 to 71 years. Out of 14 patients, 2 (14.29\%) had a history of the depressive disorder in the past, one had co-morbid dementia $(7.14 \%)$ and one had the co-morbid seizure disorder (7.14\%). Out of 14 patients, 4 (28.57\%) patients received psychiatric consultation; two patients were diagnosed with adjustment disorder (14.30\%), one with co-morbid autism spectrum disorder with behavioral problems (7.10\%) and one with a co-morbid recurrent depressive disorder (7.10\%). Rest of the patients $(71.40 \%)$ received psychotropics without any psychiatric evaluation or psychiatric diagnosis. Out of 14 patients, 9 patients were prescribed clonazepam 
$(64.30 \%), 3$ patients were prescribed quetiapine $(21.40 \%)$. Rest of the patients received sertraline $(7.10 \%)$ and amitriptyline $(7.10 \%)$.

\section{Discussion}

Our results indicate that psychiatric aspect was addressed in only 5.71\% of admitted cases with severe Dengue fever and only 4 patients received the proper psychiatric evaluation. There are only a few cross-sectional hospital-based observational studies regarding common psychiatric disorders in patients with acute Dengue fever. In a cross-sectional study from Pakistan, 531 consecutive patients with Dengue fever were administered the Hospital Anxiety and Depression Scale (HADS). The results showed that about $60 \%$ of the patients met criteria for anxiety and $62.2 \%$ of the patients met criteria for depression, and severity of the physical symptoms such as fever, headache, myalgia and arthralgia and the retro/periorbital pain was positively correlated with both anxiety and depression scores. ${ }^{7}$ Other studies showed that around $90 \%$ of the patients exhibited thanatophobia (fear of death), 15-23\% had panic attacks, $80 \%$ had significant anxiety-related symptoms and $60 \%$ had depressive symptoms during the acute phase of illness. ${ }^{8,9}$ Though most of this symptoms get reduced in severity with improvements in the physical condition, around 50\% of these patients developed insect phobia on recovery from Dengue fever and around $5 \%-20 \%$ of these patients had persistent depressive symptoms even after the acute phase of the illness. ${ }^{8,9}$

The exact mechanism of neuropsychiatric manifestations of Dengue infection remains unclear. Some even consider no clinical association between Dengue and psychological problem and the finding in previous case reports might be only the accidental cooccurrence of interest. ${ }^{5}$ However, cerebral edema resulting from capillary leakage, neurotropism of Dengue virus and neuroimmune-mediated response with increased pro-inflammatory cytokine levels such as Interleukin $4 / 6$ and TNF-Alpha can explain the behavioral, affective, and cognitive disturbances in Dengue infection. ${ }^{7,10}$ Moreover, animal studies also showed anxiety-like behaviors, hippocampal inflammation and neuronal apoptosis associated with Dengue virus infection in the central nervous system. ${ }^{11}$

In view of the recent epidemics of Dengue in various Indian states and all over the world, it is important to evaluate the burden of the disease on mental functioning, as untreated depression can lead to increased medical morbidity, higher healthcare costs, and can delay or prevent recovery from medical illness.

\section{References}

1. Monath TP. Dengue: The risk to developed and developing countries. Proc Nail Academy Science USA 1994;91:2395-400.

2. Thomas SJ, Strickman D, Vaughn DW. Dengue epidemiology: Virus epidemiology, ecology, and emergence. Advances in Virus Research 2003;61:235-89.

3. Patz JA, Daszak P, Tabor GM, Aguirre AA, Pearl M, Epstein J, Wolfe ND, Kilpatrick AM, Foufopoulos J, Molyneux D, Bradley DJ. Working group on land use change and disease emergence. Unhealthy landscapes: Policy recommendations on land use change and infectious disease emergence. Environmental Health Perspectives 2004; 112(10):1092-8.

4. Gulati S, Maheshwari A, authors. Atypical manifestations of Dengue. Trop Med Int Health 2007;12:1087-95. 
5. Wiwanitkit S \& Wiwanitkit V. Psychological Manifestation in Dengue: Did it Really exist? Indian Journal of Psychological Medicine 2013;35(2):222.

6. Blum JA, Pfeifer S, Hatz CF. Psychiatric manifestations as the leading symptom in an expatriate with Dengue fever. Infection 2010;38:341-3.

7. Hashmi AM, Butt Z, Idrees Z et al. Anxiety and depression symptoms in patients with Dengue fever and their correlation with symptom severity. Int J Psychiatry Med 2012;44:199-210.

8. Jhanjee A, Bhatia MS, Srivastava S, Rathi A. A study of psychiatric symptomatology in Dengue patients. Delhi Psychiatry J 2013;16: 21-3.

9. Gill KU, Ahmad W, Irfan M. A clinical study to see the psychological effects of Dengue fever. Pak J Med Health Sci 2011;5: 101-4.

10. Bhatia MS, Saha R. Neuropsychiatric manifestations in Dengue fever. Med J DY Patil Univ 2017;10:204-6.

11. de Miranda AS. Dengue-3 encephalitis promotes anxiety-like behavior in mice. Behavioural Brain Research 2012; 230:237-42. 